\title{
Economic Use of Water in Drip-Irrigated Maize in Semi-Arid Region of Brazil
}

\author{
Samuel Silva ${ }^{1}$, Rafaela Felix Basílio Guimarães ${ }^{2}$, Ronaldo do Nascimento ${ }^{2}$, Hallyson de Oliveira ${ }^{2}$, Iêdo Teodoro ${ }^{3}$, \\ José Alberto Ferreira Cardoso ${ }^{4}$, Carlos Vailan de Castro Bezerra ${ }^{2} \&$ Jailson Lopes da Penha $^{2}$ \\ ${ }^{1}$ Instituto Federal de Alagoas, Campus Piranhas, Maceió, Brazil \\ ${ }^{2}$ Universidade Federal de Campina Grande, Campina Grande, Brazil \\ ${ }^{3}$ Universidade Federal de Alagoas, Maceió, Brazil \\ ${ }^{4}$ Instituto Federal do Tocantis, Palmas, Brazil \\ Correspondence: Rafaela Felix Basílio Guimarães, Universidade Federal de Campina Grande, Campina Grande, \\ Brazil. E-mail: rafaellafelix_@hotmail.com
}

Received: November 30, 2017 Accepted: January 3, $2018 \quad$ Online Published: February 15, 2018

doi:10.5539/jas.v10n3p364 URL: https://doi.org/10.5539/jas.v10n3p364

\begin{abstract}
The objective of this study was to determine the economic level of drip irrigation for the crop of maize in the region of backwoods of Alagoas in Brazil, aiming at a sustainable production and economically viable. For this, the hybrid AG7088 was submitted to five irrigation levels (40, 80, 120, 160 and 200\% of ETc) in an experiment developed at the Federal Institute of Alagoas/Campus Piranhas, with a randomized block design and four replications. Harvesting was carried out 98 days after planting, where grain yield with $12 \%$ moisture reached 2.1 and $11.8 \mathrm{Mg} \mathrm{ha}^{-1}$ and water use efficiency of 181.8 and $55.3 \mathrm{~mm} \mathrm{Mg}^{-1}$ in treatments with 40 and $160 \%$ of ETc, respectively. The maximum a physical productivity estimated by the production function was $11.3 \mathrm{Mg} \mathrm{h}{ }^{-1}$, obtained with $919 \mathrm{~mm}$ of irrigation water. The maximum economic yield was $11.1 \mathrm{Mg}^{-1}$, obtained with level of $841 \mathrm{~mm}(160 \% \mathrm{ETc})$.
\end{abstract}

Keywords: cost of water for irrigation, drip irrigation, grain yield

\section{Introduction}

Maize is an of the most cereals consumed in the Northeast region of Brazil, both as an industrialized product and in natura, due to its use in human and animal feed, as well as exercises an important socioeconomic role for the region (Cruz et al., 2006). According to the National Supply Company (CONAB, 2017), Bahia (1.98 million t and $\left.3.0 \mathrm{t} \mathrm{ha}^{-1}\right)$, Maranhão (1.95 million $\mathrm{t}$ and $\left.3.9 \mathrm{t} \mathrm{ha}^{-1}\right)$ and Piaú $\left(1.38\right.$ million $\mathrm{t}$ and $\left.2.9 \mathrm{t} \mathrm{ha}^{-1}\right)$ were the Northeastern States that more produced maize in the 2015/16. Alagoas occupied the eighth place, with annual production of 25.1 thousand tons and average yield of approximately $0.6 \mathrm{t} \mathrm{ha}^{-1}$. This low agricultural yield compared to the other NE States (mean of $2.5 \mathrm{t} \mathrm{ha}^{-1}$ ) occurs mainly due to the irregular distribution of rainfall.

The cultivation of maize in this region predominates in the rainy season, which occurs from April to August, but in some years occurs in periods without rain and the crop is subject to water deficit (Carvalho, Souza, Lyra, \& Silva, 2013). The water can interfere in the plant physiology, absorption dynamics and nutrient utilization, due it is the vehicle of conduction of the nutrients to the root-soil interface and in the xylem, (Ferreira, Magalhães, Durães, Vasconcellos, \& de Araujo Neto, 2008). According to Brito et al. (2013), the occurrence of water deficit during the feeding and the filling of the grains causes losses in the agricultural productivity, because in this phase occurs the synthesis of components of the yield. Thus, the maize water requirement, which is 200 to $400 \mathrm{~mm}$ during the production cycle (Bergamaschi et al., 2006), when not fully supplied by rainfall, should be complemented by irrigation.

Irrigation, in this sense, besides supplying this deficiency, may favor the cultivation of other crops during the dry season. However, the improper use of water resources in irrigated agriculture, due to the search for higher yields has contributed to the high waste of water, resulting in undesirable consequences for the environment (Bizari, Matsura, Deus, \& Mesquita, 2011). Thus, to use it economically in irrigation projects, it is necessary to know the water consumption by the crop and its response in productivity, the atmospheric demand and the physical-water characteristics of the soil to determine the economic irrigation level. In addition, it is convenient to make use of 
localized irrigation systems, which present better efficiency and uniformity of water application, low energy consumption and keep soil moisture always close to field capacity (Boas, Pereira, Reis, Lima Junior, \& Consoni, 2011). Thus, the objective of this study was to determine the drip irrigation level with the greatest economic efficiency for the maize crop in the backwoods region of Alagoas, in order to define the appropriate management and the adoption of sustainable practices with the water use efficient for this culture.

\section{Material and Methods}

The experiment was conducted at the Federal Institute of Alagoas/Campus Piranhas, in the Alagoas State, Brazil, during the months of December 2016 to March 2017. The climatic classification of the region, according to Köppen, is of the Bsh type, very hot climate, semi-arid, steppe-type, with a rainy season centered in the months of April, May and June. The average annual rainfall of the region is $483 \mathrm{~mm}$ (Sousa et al., 2010). The soil of the area is classified as Salic-Sodic Orthic Chromic Luvisol of clay texture (Fernandes, Ribeiro, Oliveira, \& Ferreira, 2010). Agroceres AG7088 hybrid was used, with a population of 62.500 plants per hectare, in a randomized block design with four replications. The treatments were five irrigation levels $(\mathrm{L} 1=40, \mathrm{~L} 2=80, \mathrm{~L} 3=120, \mathrm{~L} 4=$ 160 and $\mathrm{L} 5=200 \%$ of ETc).

The fertilization occurred in function of an expected yield of $10 \mathrm{tha}^{-1}$, based on the average nutrient extraction by the maize crop destined to the production of grains, according to Coelho (2006), being part in foundation and nitrogen fertilization in cover at 15 days after planting (DAP). The irrigation was done via a drip system with a water flow of $1.5 \mathrm{~L} \mathrm{~h}^{-1}$, nominal pressure of $10 \mathrm{mca}$ and spacing between drippers of $40 \mathrm{~cm}$. In the first 20 DAP all treatments were irrigated with the same level, in which was applied a level of $6 \mathrm{~mm}$ per day to meet the germination, based on the evapotranspiration of culture (ETc). From this period (beginning of the crop growth phase), the irrigation levels were differentiated according to the treatments with irrigation frequency of 2 days, in which from the 34 DAP there was variation of pressure in the catchment system and caused variability in the calculated levels for treatments. The average daily values of the levels were 3, 6, 9, 12 and $14.3 \mathrm{~mm}$ in L1, L2, L3, L4 and L5, respectively. The meteorological data for estimation of ETc were obtained in an automatic station of acquisition of data belonging to the IFAL/Piranhas and located near the experimental area. The reference evapotranspiration (ETo) was calculated by the Penman Monteith method (Allen, Pereira, Raes, \& Smith, 1998) to make water balance in the soil (with root depth varying from 0.10 to $0.40 \mathrm{~m}$ ) and to estimate ETc. The values of crop coefficient $(\mathrm{Kc})$ used were $0.9,1.2$ and 0.5 in the initial period, midseason and at harvest, respectively.

Due the harvesting at the physiological maturation stage, the grains were placed in a drying oven until reached the moisture about $12 \%$ and the maize yield was determined by the average grain weight. Through grain yield data and ETc, was determined the water use efficiency (WUE) by the crop in the form of consumption, in mm per megagrama, based on the methodology cited by Dantas Junior and Chaves (2014).

The production function of the crop to estimate the maximum physical and economic productivity was obtained according to the methodology developed by Frizzone (1993). For the economic analysis of production, the price of the millimeter of water was calculated based on the costs of farmers who use drip irrigation systems and had these costs monitored during the last three years (Table 1). The selling prices of maize bag $(60 \mathrm{~kg})$ used for the calculation of remuneration were three equidistant values $(\mathrm{R} \$ 30.00, \mathrm{R} \$ 45.00$ and $\mathrm{R} \$ 60.00)$ due to the variation of the quotation during the harvests, to be used as comparatives in administrative decision making. The values of economic productivity calculated for each price of corn sack were statistically compared, where the mean Confidence Interval $(1-\alpha)$ was used, with $\alpha=5 \%$ of significant error.

Table 1. Cost of the water millimeter for drip irrigation in the maize crop

\begin{tabular}{|c|c|c|c|}
\hline Descrition & $\mathrm{R} \$$ ha $^{-1}$ cycle $^{-1}$ & $\mathrm{R} \$ \mathrm{~mm}^{-1}$ & $\%$ \\
\hline Hydraulic Infrastructure/Buildings (amortized in 20 years - 60 harvests) & 46.67 & 0.12 & 8.3 \\
\hline Irrigation system (amortized in 10 years - 30 harvests) & 166.67 & 0.42 & 29.6 \\
\hline Annual operating cost of irrigation & 350.00 & 0.88 & 62.1 \\
\hline Total cost of irrigation per production cycle & 563.33 & 1.41 & 100 \\
\hline \multicolumn{4}{|l|}{ Operation of the irrigation system during 3 production cycles per year } \\
\hline Average depth irrigation per cycle: $400 \mathrm{~mm}$ & & & \\
\hline
\end{tabular}

\section{Results and Discussion}

Rainfall during the maize production cycle (12/23/2016 to 03/30/2017-98 days) totaled $42.2 \mathrm{~mm}$, and $61 \%$ $(25.8 \mathrm{~mm})$ of this rainfall occurred only in one day $(02 / 21 / 2017)$, characterizing irregular distribution of rainfall 
during the cultivation period (Figure 1). However, this period of the year does not correspond to the region's rainy season.

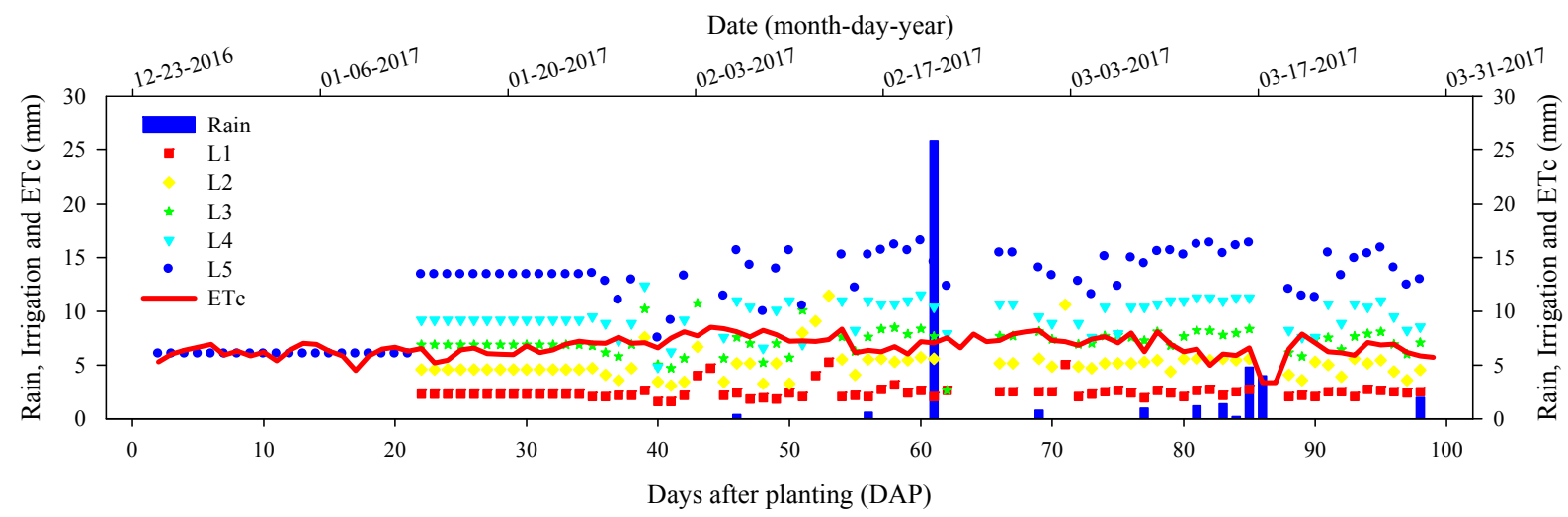

Figure 1. Daily values of rainfall, crop evapotranspiration (ETc) and irrigation levels of the treatments (L1, L2, L3, L4 and L5) during the maize crop cycle, from December 2016 to March 2017 in the region of Piranhas-AL

Total crop evapotranspiration (ETc) in the crop cycle was $654 \mathrm{~mm}$, with a minimum of $3.4 \mathrm{~mm} \mathrm{day}^{-1}$ (March 17 and 18, 2017), maximum $8.5 \mathrm{~mm} \mathrm{day}^{-1}$ (February 3, 2017) and a mean of $6.7 \mathrm{~mm} \mathrm{dia}^{-1}$ (Figure 1). Lower values of ETc are observed in the period when there is rainfall, when there is high cloudiness and a decrease in the intensity of the solar radiation, the warming of the atmosphere and, consequently, the atmospheric demand.

During all the initial phase of the crop (0-20 DAP), all treatments had soil water storage equal to the total available water (TAW $=20 \mathrm{~mm}$ ), due to irrigation during this period (Figure 2). From the growth phase the L1 and L2 storage was below the limit of the readily available water (RAW) in most of the days due to the fact of the subirrigation, especially when the crop was in maximum growth, where the water deficit was great intensity. In the treatments L3, L4 and L5 the storage remained close to the TAW throughout the production cycle, since they were irrigated with levels larger than the ETc. There were some reductions in storage from these treatments due to problems of pressure in the system, but not enough to compromise the culture.
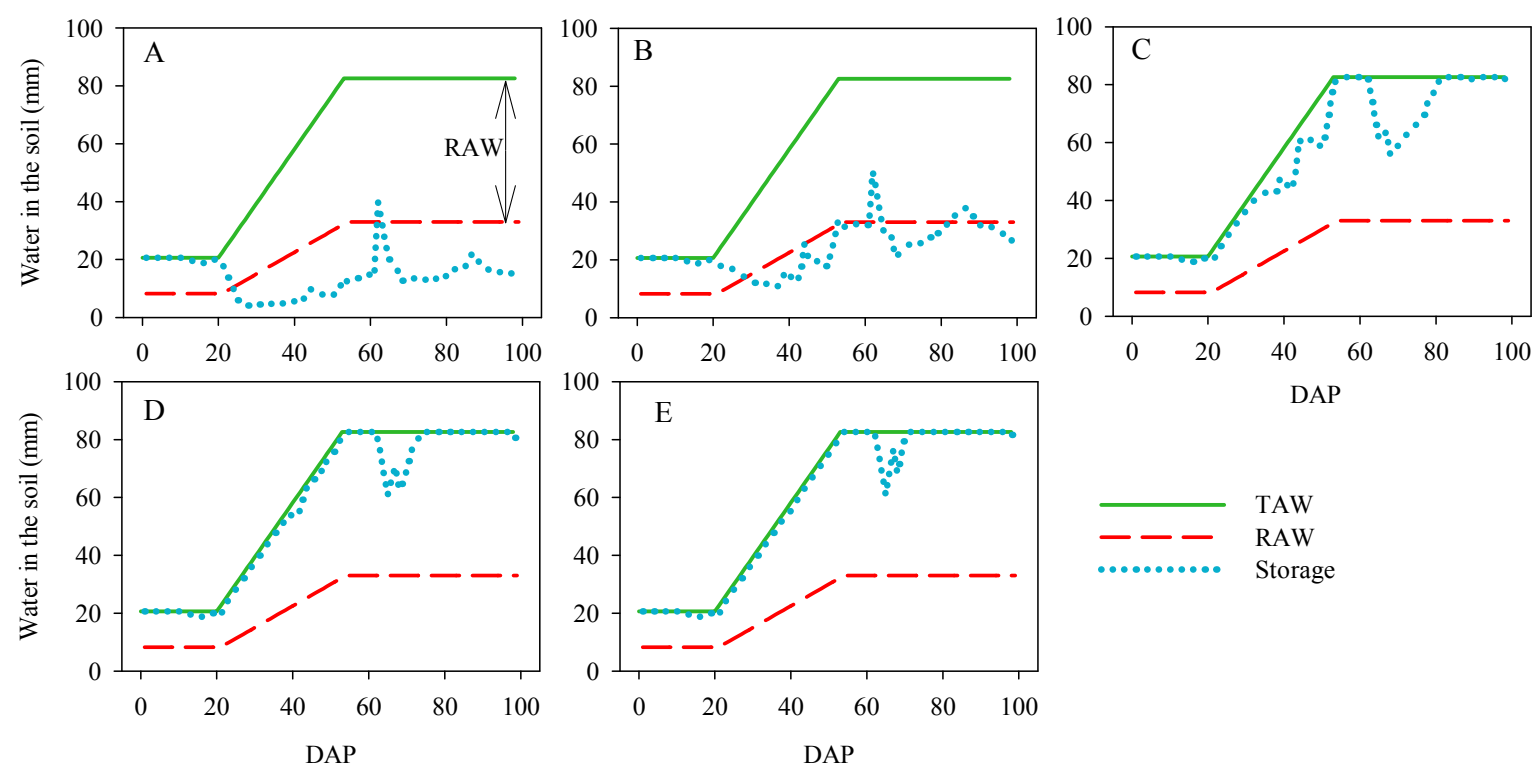

Figure 2. Daily values of the total available water in the root zone (TAW), the limit of the readily available water (RAW) and storage of water in the soil (Storage) for treatments with different irrigation levels L1 (A), L2 (B), L3 (C), L4 (D) and L5 (E) during the maize crop cycle, from December 2016 to March 2017 in the Piranhas-AL 
Differentiated total irrigation levels ranged from 206 to $1.056 \mathrm{~mm}$ and, except for the L1 treatment, all the others exceeded the ETc percentage established (Table 2). This was due to the variation of pressure in the catchment system from the 34 DAP. Total ETc during the period of application of the differentiated levels was $525 \mathrm{~mm}$.

Table 2. Total irrigation values, ETc percentage reached by levels and total crop evapotranspiration (ETc) for treatments with different irrigation levels in maize crop, from December 2016 to March 2017, in the Piranhas-AL.

\begin{tabular}{llll}
\hline Treatments & Irrigation Depth $(\mathrm{mm})$ & $\%$ of reached ETc & ETc $(\mathrm{mm})$ \\
\hline L1 $(40 \%$ ETc) & 206 & $39 \%$ & \\
L2 $(80 \%$ ETc) & 428 & $82 \%$ & 525 \\
L3 $(120 \%$ ETc) & 634 & $121 \%$ & \\
L4 $(160 \%$ ETc) & 849 & $162 \%$ & \\
L5 $(200 \%$ ETc) & 1.056 & $201 \%$ & \\
\hline
\end{tabular}

The L4 treatment produced almost five times more than L1, in which the maize yield in function of total irrigation level ranged from 2.1 to $11.8 \mathrm{Mg} \mathrm{ha}^{-1}$ in L1 and L4, respectively (Figure 3A). The L5 treatment had lower yield than L4 and this behavior is in accordance with the law of diminishing returns, which corresponds to the analysis of response by the agronomic principle known as "law of the minimum" developed by Carl Sprengel in 1828 and later popularized by Von Liebig in 1840. This law says that "the yield of any crop is governed by any change in the quantity and quality of the scarce factor, called the minimum factor. And, to the extent that the minimum factor is increased, yield also increases in proportion to the supply of that factor until another factor becomes minimal". In the case of over-supply of the factor, the crop tends to reduce yield by reaching its stress zone by excess.
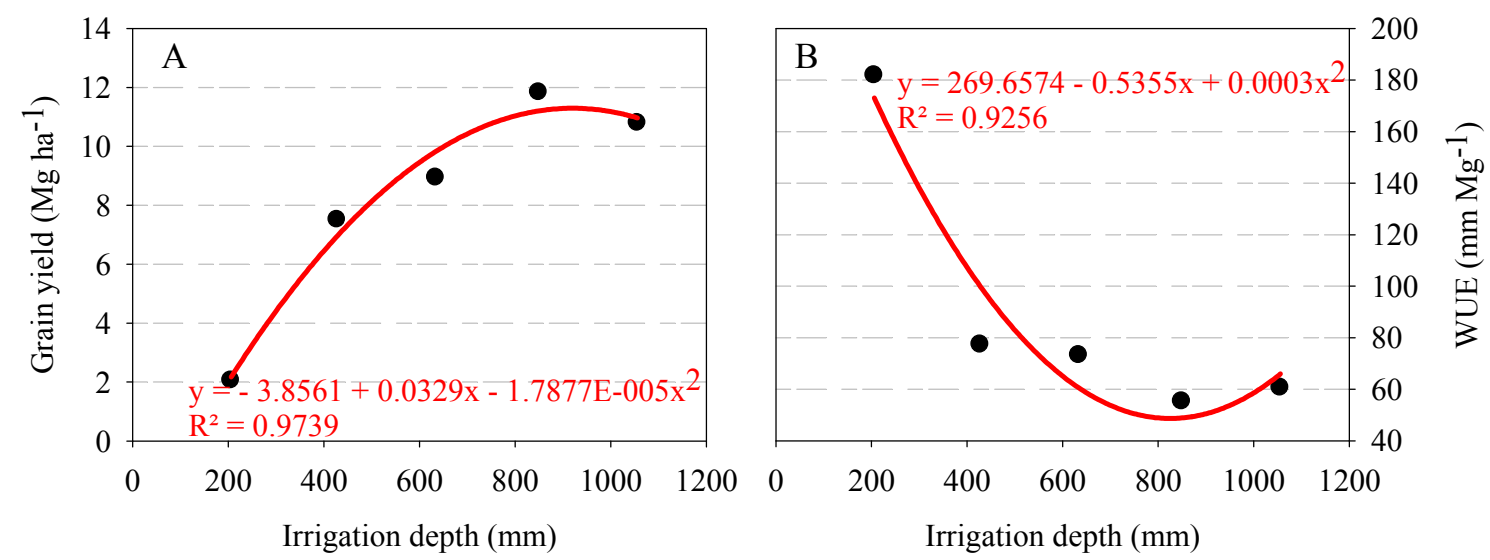

Figure 3. Agricultural productivity (A) and water use efficiency (B) of maize in function of irrigation levels during cultivation, from December 2016 to March 2017, in Piranhas-AL

The water use efficiency (Figure 3B) in the form of consumption decreased from 181.8 to $55.3 \mathrm{~mm} \mathrm{Mg}^{-1}$ in the treatments with 40 and $160 \%$ of ETc, respectively, indicating that when irrigation approaches the conditions of cultivation without water deficiencies a WUE is lower and corroborates with the conclusions of Frizzone (1993). Dantas Junior and Chaves (2014) cultivated green maize irrigated with levels of water between 25 and $150 \%$ of ETc and also found that the WUE decreased with the increase of the amount of water applied through irrigation.

The production function presented significant adjustment, in which the coefficient of determination of the equation $\left(\mathrm{R}^{2}\right)$ was $97 \%$, since in the observed values there was a maximum point followed by a decrease. According to Silva et al. (2015), the second-degree polynomial is one of the most used mathematical equations as a production function. However, production functions should, in general, be used at convenient intervals, that is, without exceeding economically reasonable input levels. 
The maximum physical productivity of the crop, estimated by the production function, was $11.3 \mathrm{Mg}^{-1}$ (Table $3)$, obtained with a total irrigation level of $919 \mathrm{~mm}(175 \%$ of ETc). For productivity above this value, that is, with the crop under optimum conditions of soil moisture, other agricultural practices, such as fertilization, pest and disease control, and others must be used. It is observed that there wasn't significant change in economic productivity as a function of the sale price of maize, since the values are within the confidence interval (CI) of the mean. In this case, the lowest value of the economical level $(841 \mathrm{~mm}, 160 \%$ of ETc) is chosen to avoid water waste and higher operating costs. However, the producer must pay attention to the fact that the economic level depends of the price relation of water (Px) and grain (Py) and not of the prices properly, that is, when the mm becomes more expensive in relation to $\mathrm{kg}$ of grain maize, the economic level decreases, and vice versa.

Table 3. Values of levels irrigation and economic productivity for different selling prices of maize cultivated between December 2016 and March 2017, in the region of Piranhas-AL

\begin{tabular}{lll}
\hline Price of bag $(\mathrm{R} \$)$ & Econonmic irrigation level $(\mathrm{mm})$ & Economic crop yield $\left(\mathrm{Mg} \mathrm{ha}^{-1}\right)$ \\
\hline 30.00 & 841 & 11.16 \\
45.00 & 867 & 11.22 \\
60.00 & 880 & 11.25 \\
Mean & 862 & $11.21(\mathrm{CI}=11,14$ to 11,28$)$ \\
Maximum level $(\mathrm{mm})$ & & Maximum yield $\left(\mathrm{Mg} \mathrm{ha}^{1}\right)$ \\
919 & & 11.30
\end{tabular}

The calculation of input costs in agriculture for maximum economic return involves several factors that can not always be controlled, especially when it comes to environmental factors. Therefore, works like this serve to be taken as basis in administrative decisions, provided that the conditions are similar to those of the place where the research was carried out. In addition, economic issues such as input prices and agricultural commodities are subject to change on a daily basis, being left to the discretion of the administrator to seek the best solution and to choose the most viable alternative for the use of certain inputs.

\section{Conclusions}

The economic level of drip irrigation for maize in the Piranhas-AL region with cultivars of genetic potential similar to the one used in this experiment is around $160 \%$ of the ETc, where it is possible to obtain grain yields above $11 \mathrm{Mg} \mathrm{ha}^{-1}$.

\section{References}

Allen, R. A., Pereira, L. S., Raes, D., \& Smith, M. (1998). Crop evapotranspiration: Guidelines for computing crop requerimentns. Irrigation and Drainage Paper, 56 (p. 328). Roma: FAO. Retrieved from http://www.fao.org/docrep/X0490E/X0490E00.htm

Bergamaschi, H., Dalmago, G. A., Comiran, F., Bergonci, J. I., Muller, A. G., França, S., ... Pereira, P. G. (2006). Deficit hídrico e produtividade na cultura do milho. Pesquisa Agropecuária Brasileira, 41(2), $243-249$. https://doi.org/10.1590/S0100-204X2006000200008

Bizari, D. R., Matsura, E. M., Deus, F. P., \& Mesquita, M. (2011). Diferentes sistemas de manejo do solo no consumo de água do feijoeiro irrigado em Campinas-SP. Revista Brasileira de Agricultura Irrigada, 5(3), 143-152. https://doi.org/10.7127/RBAI.V5N300049

Boas, R. C. V., Pereira, G. M., Reis, R. P., Lima Junior, J. A., \& Consoni, R. (2011). Viabilidade econômica do uso do sistema de irrigação por gotejamento na cultura da cebola. Ciência e Agrotecnologia, 35(4), 781-788. https://doi.org/10.1590/S1413-70542011000400018

Brito, M. E. B., de Araújo Filho, G. D., Wanderley, J. A. C., de Melo, A. S., da Costa, F. B., \& Ferreira, M. G. P. (2013). Crescimento, fisiologia e produção do milho doce sob estresse hídrico. Bioscience Journal, 29(5), 1244-1254. Retrieved from http://www.seer.ufu.br/index.php/biosciencejournal/article/view/14061/13019

Carvalho, A. L., de Souza, J. L., Lyra, G. B., \& da Silva, E. C. (2013). Estação chuvosa e de cultivo para a região de rio largo, alagoas baseada em métodos diretos e sua relação com o el niño-oscilação sul. Revista Brasileira de Meteorologia, 28(2), 192-198. https://doi.org/10.1590/S0102-77862013000200008

Coelho, A. M. (2006). Nutrição e adubação do milho. Circular Técnica, 78. Sete Lagoas: Embrapa Milho e Sorgo. Retrieved from https://www.infoteca.cnptia.embrapa.br/handle/doc/490410 
CONAB (Companhia Nacional De Abastecimento). (2017). Acompanhamento da safra brasileira de grãos 2016/17 (p. 158). Décimo Segundo Levantamento, Brasília: CONAB. Retrieved from http://www.conab. gov.br/OlalaCMS/uploads/arquivos/17_09_12_10_14_36_boletim_graos_setembro_2017.pdf

Cruz, J. C., Konzen, E. A., Pereira Filho, I. A., Marriel, I. E., Cruz, I., Duarte, J. de O., ... Alvarenga, R. C. (2006). Produção de milho orgânico na agricultura familiar. Circular Técnica, 81. Sete Lagoas: Embrapa Milho e Sorgo. Retrieved from https://www.embrapa.br/busca-de-publicacoes/-/publicacao/490413/ producao-de-milho-organico-na-agricultura-familiar

Dantas Junior, E. E., \& Chaves, L. H. G. (2014). Yield and Water Use Efficiency of Green Maize Planted in Conditions Brazilian Semiarid. Agricultural Sciences, 5(6), 498-503. https://doi.org/10.4236/as.2014.56051

Fernandes, L. A., Ribeiro, M. R., Oliveira, L. B., \& Ferreira, R. F. (2010). Caracterização e classificação de solos de uma litotoposseqüência do Projeto Xingó-SE. Revista Brasileira de Ciências Agrárias, 5(2), $192-201$. https://doi.org/10.5039/agraria.v5i2a675

Ferreira, V. M., Magalhães, P. C., Durães, F. O., Vasconcellos, C. A., \& de Araujo Neto, J. C. (2008). Acúmulo e distribuição de macronutrientes em dois híbridos duplos de milho, em função da disponibilidade de água no solo. Revista Brasileira de Milho e Sorgo, 7(1), 1-17. https://doi.org/10.18512/1980-6477/rbms.v7n1p1-17

Frizzone, J. A. (1993). Funções de resposta das culturas à irrigação. Série Didática, 6 (p. 43). Piracicaba: ESALQ/USP.

Silva, S., Dantas Neto, J., Teodoro, I., Silva, S. S., Nascimento, R., \& Barbosa, G. V. D. S. (2015). Economic depth of drip irrigation on sugarcane. Irriga, 1(2), 37-46. https://doi.org/10.15809/irriga.2015v1n2p37

Sousa, I. F. D., da Silva, V. D. P., Sabino, F. G., Silva, B. K., \& Azevedo, P. V. D. (2010). Evapotranspiração de referência nos perímetros irrigados do Estado de Sergipe. Revista Brasileira de Engenharia Agrícola e Ambiental, 14(6), 633-644. https://doi.org/10.1590/S1415-43662010000600010

\section{Copyrights}

Copyright for this article is retained by the author(s), with first publication rights granted to the journal.

This is an open-access article distributed under the terms and conditions of the Creative Commons Attribution license (http://creativecommons.org/licenses/by/4.0/). 